\title{
Evaluation of various methods to measure particulate bound mercury and associated artifacts
}

S. Wang ${ }^{1}$, T. M. Holsen ${ }^{1}$, J. Huang ${ }^{2}$, and Y.-J. Han ${ }^{3}$

${ }^{1}$ Department of Civil and Environmental Engineering, Clarkson University, 8 Clarkson Ave., Potsdam, NY 13699-5710, USA

${ }^{2}$ Department of Natural Resources and Environmental Sciences, University of Nevada, Reno, 1664 N. Virginia St., Reno, NV 89557, USA

${ }^{3}$ Department of Environmental Science, College of Natural Science, Kangwon National University, 192-1 Hyoja-2-dong, Chuncheon, Kangwon-do, 200-701, Republic of Korea

Received: 21 January 2013 - Accepted: 12 March 2013 - Published: 2 April 2013

Correspondence to: Y.-J. Han (youngji@kangwon.ac.kr)

Published by Copernicus Publications on behalf of the European Geosciences Union.

Particulate bound mercury and associated artifacts

S. Wang et al.

\section{Title Page}

\section{Full Screen / Esc}

Printer-friendly Version

Interactive Discussion 


\section{Abstract}

This study was performed to determine how sampling artifacts associated with various sampling methods including open faced filter (OFF) pack, micro orifice uniform deposit impactor (MOUDI), and Tekran speciation system (TekSpec) impact particulate bound

5 mercury (PBM) measurements. PBM measured by the MOUDI for $48 \mathrm{~h}$ was statistically lower than that measured with the TekSpec every $2 \mathrm{~h}$, indicating that negative artifacts were significant for long sampling durations. Negative artifacts were also identified in lab experiments as the $\mathrm{Hg}^{0}$ and $\mathrm{HgCl}_{2}$ concentrations associated with particulate matter on the filter significantly decreased when the filter was exposed to zero air. Positive 10 artifacts were also investigated. The OFF sampling for $48 \mathrm{~h}$, which is likely to be associated with both positive and negative artifacts, measured a significantly lower PBM concentration than the TekSpec while the OFF and MOUDI (48 h sampling - minimal positive artifacts) showed similar results, suggesting that positive artifacts were minor under the rural condition encountered (low atmospheric gaseous oxidized mercury and 15 typical oxidants concentrations). The $\mathrm{Hg}$ speciation associated with particles varied with atmospheric temperature, with the contribution of less volatile species including $\mathrm{HgO}$ and $\mathrm{HgS}$ increasing and more volatile $\mathrm{Hg}^{0}$ and $\mathrm{HgCl}_{2}$ decreasing as atmospheric temperature increased. There was significant correlation for PBM larger than $2.5 \mu \mathrm{m}$ between TekSpec frit and MOUDI in this study, indicating that TekSpec frit is a good alternative sampler for measuring the concentration of coarse PBM.

\section{Introduction}

Mercury $(\mathrm{Hg})$ is a globally distributed toxic pollutant (USEPA, 1997). It is emitted to the atmosphere by both natural and anthropogenic sources mainly in inorganic forms, which do not constitute a direct public health risk at the level of exposure typically found (Driscoll et al., 2007). Atmospheric Hg primarily exists in three forms; gaseous elemental $\mathrm{Hg}\left(\mathrm{Hg}^{0}\right.$ or GEM), gaseous oxidized mercury (GOM), and particulate bound mercury
ACPD

$13,8585-8614,2013$

\section{Particulate bound \\ mercury and \\ associated artifacts \\ S. Wang et al.}

Title Page 
(PBM) (Schroeder and Munthe, 1998). Most of $\mathrm{Hg}$ in ambient air exists as GEM while GOM and PBM generally contribute less than $10 \%$ of the total $\mathrm{Hg}$ measured (Lindberg and Stratton, 1998; Pirrone et al., 2010; Weiss-Penzias et al., 2009; Valente et al., 2007). However, GOM and PBM are extremely significant with respect to atmospheric 5 deposition due to their large dry deposition velocities and scavenging coefficients although a few recent studies reported considerable GEM deposition in forested areas (Zhang et al., 2009; Huang et al., 2012). After $\mathrm{Hg}$ is deposited, it may be transformed into methyl mercury (MeHg), a toxic form, by sulfate reducing and other types of bacteria in aquatic ecosystem, followed by bioaccumulation in the food chain (Flemming et 10 al., 2006; Mergler et al., 2007; US EPA, 2001). The major human exposure pathway to $\mathrm{MeHg}$ is, therefore, the consumption of contaminated fish. Hence, the quantification of atmospheric $\mathrm{Hg}$ deposition into the aquatic system is a critical step that is needed to track the fate of $\mathrm{Hg}$ in environmental media for risk analysis.

In order to estimate the amount of $\mathrm{Hg}$ deposited, it is necessary to identify the at15 mospheric concentration of speciated $\mathrm{Hg}$ including PBM. There are a few methods available to measure PBM concentrations, including the Tekran speciation unit (TekSpec) consisting of $\mathrm{KCl}$-coated denuders and quartz filters, conventional open faced filter (OFF) packs, and multi-stage impactors such as the Micro Orifice Uniform Deposit Impactor (MOUDI) which can measure concentrations and also size distributions (Keeler et al., 1995; Sheu et al., 2001; Landis et al., 2002; Lynam and Keeler, 2005). Because physical and chemical processes consistently occur in ambient air, including adsorption, nucleation, and other gas-particle partitioning mechanisms, and ambient particle concentrations and meteorological conditions are highly variable, atmospheric concentrations and size distributions of PBM are not constant (Rutter and Schauer, 2007a, b; Xiu et al., 2009; Kim et al., 2012). In addition, PBM concentrations are typically found at ultra-low levels $\left(\mathrm{pg} \mathrm{m}^{-3}\right)$; therefore, accurate quantification of PBM is one of the most difficult tasks in studies of atmospheric mercury speciation.

There have been a few studies that have attempted to identify artifacts associated with PBM measurements. Lynam and Keeler (2005) investigated the potential artifact
ACPD

$13,8585-8614,2013$

\section{Particulate bound \\ mercury and \\ associated artifacts \\ S. Wang et al.}

Title Page
Abstract

Conclusions

Tables

14

4

Back
Introduction

References

Figures

-1

Close
Full Screen / Esc

Printer-friendly Version

Interactive Discussion 
caused by ozone using a $\mathrm{KCl}$-coated denuder and quartz filter, and found that a significant portion of gaseous $\mathrm{Hg}$ was adsorbed on a denuded filter at elevated ozone concentrations possibly due to the oxidization of $\mathrm{Hg}$ during sampling. Malcolm and Keeler (2007) have also identified a sampling artifact for a conventional $\mathrm{Hg}$ sampling 5 instrument, consisting of cyclone, gold trap, $\mathrm{KCl}$-coated denuder, and filter. They found that a $12 \mathrm{~h}$ duration sample measured significantly lower PBM concentrations in $\mathrm{PM}_{10}$ (particles having diameter $<10 \mu \mathrm{m}$ ) than three successive $4 \mathrm{~h}$ samples, due to the loss of $\mathrm{Hg}$ from filters over the course of the longer sampling periods. Talbot et al. (2011) compared the PBM concentration measured with Teflon filter pack and the Tekran automated method, and found the consistently higher PBM on Teflon filter.

Although there are many studies reporting atmospheric PBM concentrations, studies identifying the size distribution of PBM are quite scarce. In addition, there have been few systematic studies identifying the artifacts associated with PBM measurements. This study was performed to determine how sampling artifacts associated with various sampling methods impact PBM measurements in a region far from large point sources. Concentrations and size distributions of PBM were measured using three difference methods including a TekSpec, MOUDI, and OFF, and compared with each other. Based on measurement data the importance of sampling artifacts was determined.

\section{Experimental and methodologies}

\subsection{Site description}

Particle samples were collected at two different sites including the Huntington Wildlife Forest (HF) in the Adirondack Park and Clarkson University (CU) in Potsdam, both in New York State (Fig. 1). At HF sampling was performed in a large open area surrounded by conifer forest and in Potsdam sampling was performed on the roof of the three-story building at $\mathrm{CU}$ which is situated about $0.5 \mathrm{~km}$ northwest of a very small airport and about $1 \mathrm{~km}$ from a main road. Both sites were not considered to be

\section{ACPD}

$13,8585-8614,2013$

\section{Particulate bound mercury and associated artifacts \\ S. Wang et al.}

Title Page

\section{Full Screen / Esc}

Printer-friendly Version

Interactive Discussion 
significantly impacted by local sources, although the HF site represents a more background site.

Atmospheric temperatures measured at Massena International Airport station (32 km north of the CU sampling site), obtained from the National Virtual Data System website operated by NOAA (www.ncdc.noaa.gov) were used in this study.

\subsection{Sampling and analysis for PBM}

A five-stage MOUDI (MSP corp.) was used to collect size segregated PBM (nominal cut points of $10 \mu \mathrm{m}, 5.6 \mu \mathrm{m}, 3.2 \mu \mathrm{m}, 1.0 \mu \mathrm{m}$, and $0.18 \mu \mathrm{m}$ ) on quartz filters ( $47 \mathrm{~mm}$ with pore size of $0.2 \mu \mathrm{m}$ ) using a flow rate of $30 \mathrm{Lpm}$. The sampling durations for MOUDI were 2 days at $\mathrm{CU}$ and 7 days at HF. At CU 16 sets of samples were collected using the MOUDI from 15 March to 14 May 2012 while 8 sets of samples were collected at HF from 11 January to 28 February 2012. After sampling, the quartz filters were placed in the quartz container and flushed with zero air until the concentration reading of a Tekran 2537 dropped to $<0.5 \mathrm{ng} \mathrm{m}^{-3}$. The filters in the quartz container were then thermally desorbed using a furnace at $700^{\circ} \mathrm{C}$ (the limit of the furnace used) to convert desorbed $\mathrm{Hg}$ to $\mathrm{Hg}^{0}$ in a carrier gas of zero air, and introduced into a Tekran 2537B until the measured concentration dropped to $<0.5 \mathrm{ng} \mathrm{m}^{-3}$. Inside the quartz container quartz chips and glass wool were inserted to decrease the retention time and to convert the desorbed $\mathrm{Hg}$ to GEM. Detailed information about the analysis system can be found in Huang et al. (2011) and Lai et al. (2011).

A TekSpec consisting of Tekran 1130, 1135 and 2537 was used to measure GEM, GOM, and PBM concentrations during the same sampling period as the MOUDI at CU and HF. The system was operated in accordance with the EPA Mercury Monitoring network guidelines (Landis et al., 2002; NADP, 2008). Ambient air was drawn through an elutriator to remove particles $>2.5 \mu \mathrm{m}$, through a potassium chloride $(\mathrm{KCl})$ coated annular denuder to remove GOM, and then through a regenerable particulate filter (RPF) to capture PBM at a flow rate of $10 \mathrm{Lpm}$. GOM and PBM were collected with a $2 \mathrm{~h}$ sampling interval followed by a $1 \mathrm{~h}$ thermal desorption period. Additional details for

Particulate bound mercury and associated artifacts

S. Wang et al.

Title Page

Abstract Introduction

Conclusions

Tables

References

Figures

14

-I

4

Back

$>$

Close

Full Screen / Esc

Printer-friendly Version

Interactive Discussion 
TekSpec are provided in other publications (Choi et al., 2008; Kim et al., 2009; Poissant et al., 2005).

An OFF method was also used to measure the total PBM. A quartz filter was placed in a Teflon filter holder which was connected to a pump operating at a flow rate of $515 \mathrm{Lpm}$. The height of OFF was same as the height of MOUDI inlet. The sampling durations were 2 days at $\mathrm{CU}$ and 7 days at HF during same sampling period as the MOUDI. Intotal 16 and 8 samples were collected at CU and at HF, respectively. After sampling, the filters were analyzed using the same method as MOUDI filters.

A novel Large Particle Inlet (LPI), filter holder, and vacuum pump were also used 10 for artifact evaluation. The inlet was first developed to collect large particles by Lee et al. (2008). A pre-baked glass fiber filter $(10.5 \mathrm{~cm}$ diameter, pore size of $1 \mu \mathrm{m})$ was placed in the filter holder connected to the LPI, and large particles were collected at a flow rate greater than $800 \mathrm{Lpm}$. Filters were weighed before and after sampling to measure the mass of collected particles. After sampling the filters were cut into eight 15 equal size wedges, and two pieces were subjected to four different treatments including (1) immediate analysis, (2) exposure to GEM, (3) exposure to zero air, and (4) exposure to zero air followed by exposure to GEM. For exposure to GEM the filters were placed in a sealed $1 \mathrm{~L}$ bottle containing known GEM concentrations for four hours. For exposure to zero air, the filters were placed into a Teflon filter holder and zero air (UHP grade) was passed through them at a flow rate of $1 \mathrm{Lpm}$ for four hours. After all treatments, the filters were thermally desorbed as described above. Another group of five LPI samples was also used only for evaluating positive artifacts. In these experiments each filter was divided into eight equal size wedges, and two pieces were exposed to different GEM concentrations.

$25 \mathrm{Hg}$ speciation in collected particles was also identified using a thermally induced desorption technique (Feng et al., 2004). In this study, Hg desorbed from the particles collected on an OFF were quantified at desorption temperature ranges of 30$120^{\circ} \mathrm{C}, 120-350^{\circ} \mathrm{C}, 350-500^{\circ} \mathrm{C}$ and $500-700^{\circ} \mathrm{C}$ corresponding to the initial release

\section{Particulate bound mercury and associated artifacts \\ S. Wang et al.}

Title Page 
temperatures of $\mathrm{Hg}^{0}, \mathrm{HgCl}_{2}, \mathrm{HgS}$, and $\mathrm{HgO}$ from airborne particulate matter of 80 , 130,330 and $440{ }^{\circ} \mathrm{C}$, respectively (Feng et al., 2004).

\subsection{QA/QC}

All glassware and Teflon products were acid-cleaned before sampling and analysis fol-

5 lowing EPA Method 1631E (US EPA, 2002). Recoveries of SRM 1633d and Reference Soil SO-2 added to filters were $80 \pm 13 \%$ and $78 \pm 10 \%$, respectively. Average blank values for quartz filters were $12.0 \pm 7.3 \mathrm{pg}$, which was $<10 \%$ of typical sample values.

GEM concentrations measured by TekSpec were always above the published detection limit of $0.1 \mathrm{ng} \mathrm{m}^{-3}$ (Tekran, 2001). The instrumental detection limits for GOM and 10 PBM were calculated as three times the standard deviation of system blanks, and they were 0.5 and $1.1 \mathrm{pg} \mathrm{m}^{-3}$, respectively. Automatic $\mathrm{Hg}$ internal calibration was performed every $72 \mathrm{~h}$, and the flow rate for TekSpec was manually adjusted every two weeks using a volumetric flow meter.

\subsection{Statistical analysis}

15 Most of data in this study are not normally distributed; therefore, non-parametric tests were used. In order to statistically compare two datasets the Mann-Whitney $U$ test was used. To identify whether there was a statistically significant correlation between two sets of variables, Spearman rank-order $\left(r_{\mathrm{s}}\right)$ correlation coefficients were used. All the statistical analysis was conducted using the SPSS (Statistical Package for the Social Sciences, Ver. 12).

Particulate bound mercury and associated artifacts

S. Wang et al.

Title Page

\section{Full Screen / Esc}

Printer-friendly Version

Interactive Discussion 


\section{Results and discussion}

\subsection{Size distribution of PBM}

Between 15 March and 14 May, sixteen $48 \mathrm{~h}$ samples were collected using the MOUDI at CU. The mean total PBM ( $\sum$ PBM) concentration was $6.29 \mathrm{pg} \mathrm{m}^{-3}\left(2.6-23.6 \mathrm{pg} \mathrm{m}^{-3}\right)$, 5 similar to concentration ranges found in Korea (1.0-18.5 $\left.\mathrm{pg} \mathrm{m}^{-3}\right)(\mathrm{Kim}$ et al., 2012), in Florida (1-29 $\mathrm{pg} \mathrm{m}^{-3}$ ) (Graney et al., 2004) and in Wisconsin (2.1-28 $\mathrm{pg} \mathrm{m}^{-3}$ ) (Lamborg et al., 1995) in the USA, and in Ontario, Canada $\left(0.0-35.2 \mathrm{pg} \mathrm{m}^{-3}\right.$ ) (Cobbet et al., 2007). Since most of the $\mathrm{Hg}$ exists in the gaseous phase in ambient air a significant portion of the PBM may be formed by gas-particle partitioning (Andersson et al., 2007;

$10 \mathrm{Kim}$ et al., 2009; Ci et al., 2011) although in this region wood-smoke is a significant source of PBM (Huang et al., 2011). The majority of PBM was found in the 0.18$1.0 \mu \mathrm{m}$ stage; however, its contribution to $\sum$ PBM varied significantly, from $25.7 \%$ to $69.5 \%$. Rutter and Schauer (2007a, b) and Kim et al. (2012) found that PBM in the fine mode was significantly enhanced at low temperatures since the partitioning of

$15 \mathrm{Hg}$ onto particles increased as the temperature decreased and the partitioning of $\mathrm{Hg}$ occurred more effectively to fine aerosol. In this study, the fine PBM mode $(<1 \mu \mathrm{m})$ was dominant when the atmospheric temperature was low $\left(<10^{\circ} \mathrm{C}\right)$ while the PBM shifted toward to coarser mode when the atmospheric temperature was $>10^{\circ} \mathrm{C}$ (Fig. 2). Both the $\sum$ PBM concentration and the fraction of PBM (PBM in PM1/ $\sum$ PBM) significantly increased as the temperate decreased ( $p$ value $=0.01$ ) (Fig. 3$)$, possibly indicating that gas-particle partitioning of $\mathrm{Hg}$ actively occurred onto fine aerosols at low temperature. The increased concentration of fine PBM at low temperature could also result from local wood burning. Particles from wood smoke mostly exist in $<1 \mu \mathrm{m}$ size particles (Hays et al., 2002; Hosseini et al., 2010), resulting in both a high concentration of PBM and a large fraction of fine PBM when atmospheric temperatures are low.

$13,8585-8614,2013$

Particulate bound mercury and associated artifacts

S. Wang et al.

Title Page

Abstract

Introduction

Conclusions

References

Tables

Figures

14

$>1$

4 


\subsection{Comparison of various sampling method}

\subsubsection{MOUDI vs. TekSpec for $\mathrm{PBM}_{2.5}$}

Many researchers have measured concentrations of PBM in $\mathrm{PM}_{2.5}\left(\mathrm{PBM}_{2.5}\right)$ using a TekSpec equipped with an impactor and elutriator in which particles $>2.5 \mu \mathrm{m}$ are re5 moved (Lynam and Keeler, 2005; Weiss-Penzias et al., 2009). In order to compare PBM concentrations between the MOUDI and TekSpec, $\mathrm{PBM}_{2.5}$ was estimated by summing the lowest MOUDI stages and adding $68 \%$ of the particles collected in the stage of 1.0 $3.2 \mu \mathrm{m}$ (based on the ratio of $(2.5-1.0 \mu \mathrm{m})$ to $(3.2-1.0 \mu \mathrm{m})$ ). While the TekSpec $\mathrm{PBM}_{2.5}$ was approximately $26 \%$ higher than with MOUDI on average ( $p$ value $=0.026)$, the correlation between the TekSpec and MOUDI was quite good $\left(r_{\mathrm{s}}=0.944, p<0.001\right)$ (Fig. 4). Lower concentrations in the MOUDI are expected since the particles might bounce, adhere, or $\mathrm{Hg}$ may blow-off when particles strike the impaction plate, resulting in a loss of some of the mass (Hinds, 1999). In addition, the sampling duration for the MOUDI was $48 \mathrm{~h}$ while the TekSpec measured $\mathrm{PBM}_{2.5}$ every $2 \mathrm{~h}$; therefore, there might be a greater negative sampling artifact due to the volatilization of $\mathrm{PBM}_{2.5}$ after collection when the MOUDI is used. Although the TekSpec is expected to have minimal artifacts due to the short sampling time, previous research suggests that it may be associated with significant positive artifacts. Lyman et al. (2010) reported that $\mathrm{KCl}$ denuders used in TekSpec lost 29-55\% of the GOM collected in the presence of ozone, resulting in possible positive artifacts on downstream $\mathrm{PBM}_{2.5}$ collection. Loss of GOM in the denuder could cause $\mathrm{PBM}_{2.5}$ measured by the TekSpec to be higher than $\mathrm{PBM}_{2.5}$ by MOUDI if the GOM not sorbed by the denuder is sorbed by the RPF. However, if the $\mathrm{Hg}$ from the denuder is liberated as GEM as suggested by Lyman et al. (2010) the consequent positive PBM artifact will be negligible. Possible positive artifacts during PBM

At HF where the MOUDI was operated for seven days for each sample, $\mathrm{PBM}_{2.5}$ could not be compared between MOUDI and TekSpec because the last stage of the MOUDI was not used.

\section{Particulate bound mercury and associated artifacts \\ S. Wang et al.}

Title Page 


\subsubsection{MOUDI vs. TekSpec for $\mathrm{PBM}_{>2.5}$}

The TekSpec measures GOM and PBM on a short time-scale which may limit artifacts; however, the concentration of $\mathrm{PBM}>2.5 \mu \mathrm{m}\left(\mathrm{PBM}_{>2.5}\right)$ is not measured since it is removed in the impactor in order to prevent positive GOM artifacts resulting from particle

5 loss in the denuder. In this study, $\mathrm{PBM}_{>2.5}$ was measured by desorbing the removable impactor frit of the TekSpec after $48 \mathrm{~h}$ of sampling (same duration as the MOUDI samples). This concentration was compared with $\mathrm{PBM}_{>2.5}$ collected with MOUDI. On average, $\mathrm{PBM}_{>2.5}$ using the MOUDI was slightly higher than that using the TekSpec frit (Fig. 4), but the difference between the two groups was not high enough to exclude the possibility that the difference was derived by random sampling error ( $p$ value $=$ 0.462). For $\mathrm{PBM}_{>2.5}$ the TekSpec frit could also have negative artifacts due to GEM or GOM concentration decreases during the $48 \mathrm{~h}$ sampling duration similar to the MOUDI; therefore, this result cannot confirm that negative artifacts for the MOUDI were greater for $\mathrm{PBM}_{2.5}$ than for $\mathrm{PBM}_{>2.5}$. At HF where the MOUDI was operated for seven days for each sample, $\mathrm{PBM}_{>2.5}$ measured using the TekSpec frit was approximately $27 \%$ higher than that by MOUDI (but the difference was not significant; $p$ value $=0.297$ ). The correlation coefficient between two instruments did not decrease when compared with that obtained at $\mathrm{CU}$, and was still statistically significant (Fig. 4). The significant correlation between TekSpec frit and MOUDI observed (Fig. 4) indicates that TekSpec frit is a good alternative sampler for measuring the concentration of coarse PBM.

\subsubsection{Comparison with open faced filter pack (OFF)}

$\sum$ PBM concentrations measured using the MOUDI (all stages) and TekSpec (combining $\mathrm{PBM}_{2.5}$ and $\mathrm{PBM}_{>2.5}$ collected on frit) were compared with those measured by an OFF which is considered to be a conventional sampling technique for measuring PBM nificant correlation between the MOUDI and OFF ( two datasets were not different $(p$ value $=0.468)($ Fig. 5$)$ although $\sum$ PBM measured
ACPD

$13,8585-8614,2013$

\section{Particulate bound \\ mercury and \\ associated artifacts \\ S. Wang et al.}

Title Page

Abstract

Conclusions

References

Tables

Figures

14

$>1$

4

Back

Close 
by the MOUDI was approximately 1.2 times higher than $\sum$ PBM measured by the OFF. The OFF is assumed to have both negative and positive artifacts while the MOUDI is thought to have only negative artifacts since the flow streamlines do not interact with the sampling surface (Copley, 2007). Therefore, the difference between $\sum$ PBM mea5 sured by the OFF and MOUDI are due to positive artifacts (sorption of GOM), which these measurements suggest was not significant at this site.

$\sum$ PBM concentrations measured by the OFF for various sampling durations (2 days, 7 days, and 13 days) were compared with $\sum$ PBM measured by the TekSpec $\left(\mathrm{PBM}_{>2.5}+\mathrm{PBM}_{2.5}\right)$ to determine the effect of long sampling duration on PBM measure10 ments. Correlations of $\sum$ PBM measured by both methods was strong and significant $\left(r_{\mathrm{s}}=0.789, p\right.$ value $\left.<0.001\right)$; however $\sum$ PBM concentrations measured by the OFF were consistently lower (approximately $42 \%$ lower, on average) than those measured by the TekSpec ( $p$ value< 0.001 ) (Fig. 5). In contrast Talbot et al. (2011) reported that PBM measured by a OFF (Teflon filter) was consistently higher than that measured 15 by a TekSpec for both $3 \mathrm{~h}$ and $24 \mathrm{~h}$ sampling durations. They considered two possibilities with regards to this significant difference including first, that the OFF collected coarse PBM particles which were not collect by the TekSpec and second, that $\mathrm{Hg}$ from aerosols might be volatilized as they passed through the heated denuder (at $50^{\circ} \mathrm{C}$ ) as water was volatilized. The first possibility can be excluded in this study because both $\mathrm{PBM}_{2.5}$ and $\mathrm{PBM}_{>2.5}$ were measured. The second possibility examined by that Talbot et al. (2011) identified the influence of humidity on the difference between PBM measured by the OFF and TekSpec, and concluded it had minor importance; therefore, the two possibilities that Talbot et al. (2011) suggested do not explain the results seen in this study.

25 Lyman et al. (2010) found a possible positive artifact for PBM measured with the TekSpec from GOM lost from the $\mathrm{KCl}$ coated denuder and captured on the RPF. However, this positive artifact should be higher for the OFF than for TekSpec since no GOM is removed before the OFF. Therefore, the significant difference on PBM concentration between TekSpec and OFF seen in this study was likely due to a negative artifact from
ACPD

13, 8585-8614, 2013

\section{Particulate bound \\ mercury and \\ associated artifacts \\ S. Wang et al.}

Title Page
Abstract

Conclusions

Tables

14

4

Back
Introduction

References

Figures

-1

Close
Full Screen / Esc

Printer-friendly Version

Interactive Discussion 
the OFF, caused by volatilization of $\mathrm{Hg}$ from particles on the OFF during the long sampling time. When considering only the samples obtained over long sampling durations (seven and 13 days) there was no statistical correlation $\left(r_{\mathrm{s}}=0.567, p\right.$ value $=0.112$ ) between the methods suggesting that the loss of $\mathrm{Hg}$ from filters over the course of the 5 longer sampling periods should be considered when reporting PBM concentration.

To further investigate positive artifacts caused by adsorption of GOM onto the filter and/or the particles collected on filter, PBM samples were divided by two groups of high GOM and low GOM concentrations depending on when they were collected (the criterion used was the average GOM concentration, $5.4 \mathrm{pg} \mathrm{m}^{-3}$ ), and the relationships 10 between OFF and TekSpec and between OFF and MOUDI were compared. The correlation equations were TekSpec $=5.24+1.34$ OFF $\left(r_{\mathrm{s}}=0.891\right)$ and $\mathrm{MOUDI}=1.13+$ 1.11OFF $\left(r_{\mathrm{s}}=0.915\right)$ for the samples having low GOM concentrations, and TekSpec = $0.03+1.71$ OFF $\left(r_{\mathrm{s}}=0.886\right)$ and MOUDI $=0.66+1.03$ OFF $\left(r_{\mathrm{s}}=1.00\right)$ for the samples having high GOM concentrations. For both groups, the correlations were good and statistically significant at the confidence level of 0.05 , and the slope did not decrease for high GOM samples, showing that the positive artifact caused by adsorption of GOM is not significant under the conditions encountered in this study $\left(<16.5 \mathrm{pg} \mathrm{m}^{-3}\right.$ and GOM and generally low levels of other pollutants). Talbot et al. (2011) also suggested that filter based PBM had minimal positive artifact from uptake of GOM even under the conditions encountered in the marine boundary layer where GOM concentrations are typically higher.

\subsection{PBM speciation}

In only a limited number of previous studies was $\mathrm{Hg}$ speciation in particles determined. Two different approaches have been used including sequential leaching procedures 25 (Feng et al., 2000; Xiu et al., 2005, 2009) and a thermally induced desorption technique (Feng et al., 2004). In this study $\mathrm{Hg}$ desorbed from the particles collected on an OFF were quantified at different desorption temperature ranges of $30-120^{\circ} \mathrm{C}, 120-350^{\circ} \mathrm{C}$, $350-500^{\circ} \mathrm{C}$ and $500-700^{\circ} \mathrm{C}$ (Feng et al., 2004). The amount of $\mathrm{Hg}$ released in the

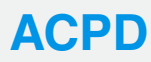

13, 8585-8614, 2013

\section{Particulate bound mercury and associated artifacts \\ S. Wang et al.}

Title Page 
temperature range of $120-350^{\circ} \mathrm{C}$ was highest, contributing $61.2 \%$ to $75.2 \%$ of the total, followed by the temperature range of $500-700^{\circ} \mathrm{C}(12.5-20.2 \%)$ (Fig. 6). In the desorption temperature range of $120-350^{\circ} \mathrm{C}$ both $\mathrm{Hg}^{0}$ and $\mathrm{HgCl}_{2}$ can be released while $\mathrm{Hg}$ released for $350-500^{\circ} \mathrm{C}$ and $500-700^{\circ} \mathrm{C}$ temperature range mostly represent $5 \mathrm{HgS}$ and $\mathrm{HgO}$, respectively (Feng et al., 2004), indicating that $\mathrm{Hg}^{0}$ and $\mathrm{HgCl}_{2}$ were the dominant forms in particles collected in this study. In the study of Feng et al. (2004) the $\mathrm{Hg}^{0}$ and $\mathrm{HgCl}_{2}$ together contributed approximately $51 \%$ of the total while $\mathrm{HgS}$ and $\mathrm{HgO}$ contributed $9 \%$ and $40 \%$ respectively, to the total $\mathrm{Hg}$ collected in Toronto. Their significantly higher contribution of $\mathrm{HgO}$ than in this study was possibly due to the fact 10 that the sampling site in Toronto was impacted to a greater extent by local sources including combustion process than the site in this study.

$\mathrm{Hg}$ speciation in particles can vary with particle composition, source type, and atmospheric temperature. Since the particles in this study were collected at one remote sampling site $(\mathrm{CU})$ and integrated over $48 \mathrm{~h}$ it is hypothesized that their composition 15 were relatively consistent for all eight samples represented in Fig. 6, indicating that atmospheric temperature ranging from $2.2^{\circ} \mathrm{C}$ to $16.7^{\circ} \mathrm{C}$ was the important factor affecting $\mathrm{Hg}$ species in particles. Previous studies found that the activation energy which the system must absorb in order to initiate a Hg release from soils (Gustin et al., 2003) was the highest for $\mathrm{HgO}$, followed by $\mathrm{HgS}, \mathrm{HgCl}_{2}$, and $\mathrm{HgO}$ (Feng et al., 2004; Koc20 man and Horvat, 2010). Therefore, it can be assumed that $\mathrm{Hg}^{0}$ and $\mathrm{HgCl}_{2}$ can more easily volatilize from the particle surface as atmospheric temperatures increase while $\mathrm{HgO}$ is much less volatile because high activation energy is required. In this study the contribution of $\mathrm{Hg}^{0}$ and $\mathrm{HgCl}_{2}$ (quantified as $\mathrm{Hg}$ desorbed at the temperature less than $350^{\circ} \mathrm{C}$ ) to total particle associated $\mathrm{Hg}$ decreased as atmospheric temperature

increased, and a positive correlation was observed between $\mathrm{HgO}$ contribution and atmospheric temperature $\left(r_{\mathrm{s}}=0.759, p\right.$ value $\left.=0.029\right)$. This result suggests that the type of $\mathrm{Hg}$ species associated with particles varies with atmospheric temperature as $\mathrm{Hg}$ species with high vaporization enthalpy increase as atmospheric temperature increases. However, it should be noted that the vaporization of $\mathrm{Hg}$ species from the

\section{ACPD}

13, 8585-8614, 2013

\section{Particulate bound mercury and associated artifacts \\ S. Wang et al.}

Title Page

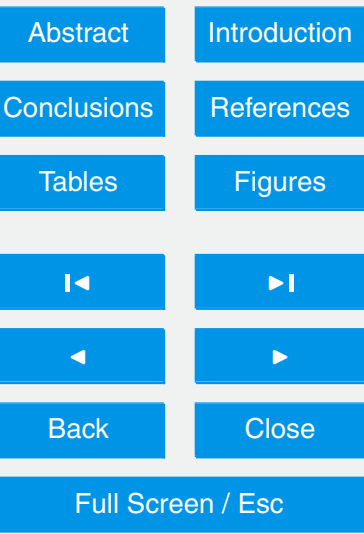

Printer-friendly Version

Interactive Discussion 
aerosol is also dependent on their binding in the aerosol, which may vary with aerosol composition.

\subsection{Artifact evaluation}

To further explore PBM artifacts, five PBM samples were obtained using the LPI sys5 tem for $36 \mathrm{~h}$. Each filter was immediately cut into eight equal size wedges and each two pieces were subjected to four different treatments including (1) immediate analysis, (2) exposure to zero air, (3) exposure to GEM, and (4) exposure to zero air followed by exposure to GEM. The exposure time for zero air and elevated GEM was $4 \mathrm{~h}$ each. The final GEM concentrations in a sealed bottle and PBM concentration on the filter $11.4 \%(7.1-16.8 \%)$ (Fig. 7). This decrease was primarily due to the loss of $\mathrm{Hg}$ species desorbed in the temperature range of $120-350^{\circ} \mathrm{C}$ (Fig. 7), indicating that either $\mathrm{Hg}^{0}$ or $\mathrm{HgCl}_{2}$ or both were the main species involved in the negative artifact. After exposure to GEM, the $\mathrm{Hg}$ mass on the filter increased $11.8 \%$ (5.8-18.8\%), at a final GEM concen5 tration of approximately $30 \mathrm{ng} \mathrm{m}^{-3}$. The increase of PBM mass was mostly detected in the desorption temperature range between 120 and $350^{\circ} \mathrm{C}$ as expected (Fig. 7). Since the GEM concentration used was much higher than ambient GEM concentrations typically found this may be the maximum positive artifact that can be caused by the sorption of GEM onto the filter and/or the particles collected on filter under the am20 bient conditions encountered. For the fourth group, the filters were exposed to zero air for $4 \mathrm{~h}$ followed by exposure to GEM in a sealed bottle for $4 \mathrm{~h}$, and the result showed that PBM mass increased only $1.8 \pm 3.3 \%$ above its original value (Fig. 7 ) even though the final GEM concentration in the bottle was approximately $30 \mathrm{ng} \mathrm{m}^{-3}$, significantly less than would be predicted from the isotherm experiments which were not exposed 25 to zero air (see below). This difference between the $\mathrm{Hg}$ mass with and without exposure to zero air may have been due to loss of $\mathrm{HgCl}_{2}$.

An additional five samples were collected using LPI system during 19 to 28 July 2012, and each filter was divided into eight equal size wedges, and two pieces were 8598
ACPD

13, 8585-8614, 2013

\section{Particulate bound mercury and associated artifacts \\ S. Wang et al.}

Title Page

Abstract Introduction

Conclusions

Tables References Figures

14 $>1$

4

Back Close Full Screen / Esc

Printer-friendly Version

Interactive Discussion 
exposed to different GEM concentrations in order to develop adsorption isotherms. The empirically derived Freundlich isotherm equation indicated there is a linear relationship between logarithmic $\omega$ (equilibrium $\mathrm{Hg}$ sorbed/particle mass; $\mathrm{ng}-\mathrm{Hg} / \mathrm{g}$-particle) and logarithmic $C_{\mathrm{a}}$ (equilibrium GEM concentration in air; $\mathrm{ng} \mathrm{m}^{-3}$ ) (Fig. $8, p$ value $<0.01$ ) as $5 \omega=94.4 C_{\mathrm{a}}^{0.037}$ where the units of $\omega$ and $C_{\mathrm{a}}$ were $\mathrm{ng} \mathrm{g}^{-1}$ and $\mathrm{ng} \mathrm{m}^{-3}$, respectively.

Previous studies on the adsorption of $\mathrm{Hg}$ were carried out in order to identify the adsorption capacity of sorbents to remove $\mathrm{Hg}$ emitted during coal combustion ( $\mathrm{Li}$ et al., 2002; Lin et al., 2006). There are also a few studies investigating $\mathrm{Hg}^{0}$ sorption by soil; however, no studies were found investigating adsorption of $\mathrm{Hg}^{0}$ by atmospheric 10 particles. In the studies of Xin and Gustin (2007) and Fang (1978), it was found that the sorption of $\mathrm{Hg}^{0}$ vapor by soil increased linearly with increasing air $\mathrm{Hg}^{0}$ concentration. The $\omega$ calculated from the study of Fang (1978) ranged from 0.15 to $0.76 \mathrm{ng} \mathrm{g}^{-1}$ for $\mathrm{C}_{\mathrm{a}}$ of $10 \mathrm{ng} \mathrm{m}^{-3}$ for various types of soil, which is significantly less than our result $\left(102.8 \mathrm{ng} \mathrm{g}^{-1}\right)$. The $\omega$ from Xin and Gustin (2007) (approximately $7 \times 10^{-4} \mathrm{ng} \mathrm{g}^{-1}$ ) was 15 also much lower than what was found in this study. In another study, Xin et al. (2007) suggested that $\mathrm{Hg}^{0}$ adsorption by soil was not concentration dependent and did not follow the typical Langmuir isotherm although they used a higher $\mathrm{Hg}^{0}$ concentrations than was used in this study (up to $170 \mathrm{ng} \mathrm{m}^{-3}$ ).

The atmospheric temperature in the lab was relatively consistent (around $20^{\circ} \mathrm{C}$ ). Fu20 ture experiments are required to determine the effect of temperature on adsorption capacity of atmospheric particles for different $\mathrm{Hg}$ species. The relatively large standard deviation of $\omega$ for similar $C_{\mathrm{a}}$ (Fig. 8) was probably due to different particle composition since the gas-particle partitioning is strongly affected by temperature, the particle surface area, and the particle surface chemistry (Liang et al., 1997; Pankow, 1991; 25

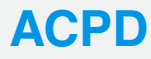

13, 8585-8614, 2013

\section{Particulate bound mercury and associated artifacts \\ S. Wang et al.}

Title Page

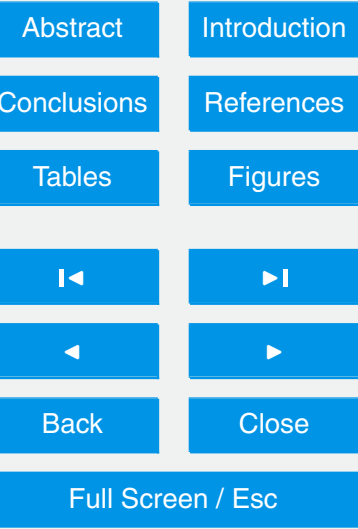

Printer-friendly Version

Interactive Discussion 


\section{Conclusion and implications}

In this study the importance of sampling artifacts was determined by comparing PBM concentrations measured by three different techniques. The concentrations of $\mathrm{PBM}_{2.5}$ measured by the MOUDI for $48 \mathrm{~h}$ were statistically lower than with the TekSpec, indi-

5 cating that negative artifacts when sampling with an impactor were significant for long sampling durations. $\mathrm{PBM}_{>2.5}$, measured by desorbing the removable impactor frit of the TekSpec after $48 \mathrm{~h}$ of sampling had no statistical difference with the MOUDI PBM $>2.5$ suggesting that both the MOUDI and TekSpec were associated with similar negative artifacts and that TekSpec frit is a good alternative sampler for measuring the concen10 tration of coarse PBM. Negative artifacts were also seen when an OFF was exposed to zero air for $4 \mathrm{~h} \mathrm{as} \mathrm{Hg}^{0}$ and $\mathrm{HgCl}_{2}$ on the filter decreased $11.4 \%$ on average. In addition, it was estimated that most of loss was attributed to $\mathrm{HgCl}_{2}$ because the PBM mass after exposure to zero air followed by exposure to GEM was far less than PBM mass after GEM exposure. This result suggests the possibility that TekSpec which collects PBM for $2 \mathrm{~h}$ at a flow rate of $10 \mathrm{Lpm}$ and is exposed to air with GOM removed, may also have negative artifacts.

OFFs, which are can potentially be associated with positive and negative artifacts, produced a statistically lower PBM concentration than the TekSpec while the OFF and MOUDI showed similar results, indicating that positive artifacts did not distort PBM measurements under the rural condition encountered in this study. It has been shown by others that gaseous $\mathrm{Hg}$ can cause positive artifacts when PBM is collected on denuded filter at elevated ozone concentrations possibly due to the oxidization of $\mathrm{Hg}$ during the sampling (Lynam and Keeler, 2005) or the decreasing collection efficiency of a denuder for GOM (Lyman et al., 2010). In the lab experiments, the filters exposed to high GEM concentration $\left(\sim 30 \mathrm{ng} \mathrm{m}^{-3}\right)$ for $4 \mathrm{~h}$ increased measured PBM $11.8 \%$, however, it cannot be concluded that positive artifacts are important under the normal atmospheric condition typically of $1-3 \mathrm{ng} \mathrm{m}^{-3}$ of GEM concentration.
ACPD

$13,8585-8614,2013$

\section{Particulate bound \\ mercury and \\ associated artifacts \\ S. Wang et al.}

Title Page

Abstract

Conclusions

References

Tables

Figures

14

-1

4

Back

Full Screen / Esc

Printer-friendly Version

Interactive Discussion 
Exposure experiments for different GEM concentrations determined the empirical Freundlich adsorption isotherm equation for $\mathrm{Hg}^{0}$ between air and the atmospheric particles as $\omega=94.4 C_{\mathrm{a}}^{0.037}$ where the units of $\omega$ and $C_{\mathrm{a}}$ were $\mathrm{ng} \mathrm{g}^{-1}$ and ng m${ }^{-3}$, respectively. Using this isotherm PBM formed by sorption of GEM can be calculated. If 5 atmospheric GEM and $\mathrm{PM}_{2.5}$ concentrations are $1.5 \mathrm{ng} \mathrm{m}^{-3}$ (typical concentration in this study area; Choi et al., 2008) and $35 \mathrm{\mu g} \mathrm{m}^{-3}$ (24 h average National Ambient Air Quality Standard), respectively, the GEM amount sorbed onto the particles is approximately $95.8 \mathrm{ng} \mathrm{g}^{-1}$ and the equilibrium atmospheric concentration of PBM in $\mathrm{PM}_{2.5}$ formed by sorption of GEM would be $3.4 \mathrm{pg} \mathrm{m}^{-3}$. If the atmospheric concentration of 10 GEM increases from 1.5 to $3.0 \mathrm{ng} \mathrm{m}^{-3}$ during PBM sampling a positive artifact can occur due to the sorption of GEM onto the particles collected on filter. Assuming the particles reach equilibrium the positive artifact would be $0.05 \mathrm{pg} \mathrm{m}^{-3}$. However, the RPF of the TekSpec is typically exchanged biweekly (Choi et al., 2008), leading to a continuous accumulation of particles over that period. If these particles, which have un15 dergone repeated heating, can also be characterized by a sorption isotherm similar to that shown above, the positive artifact could be significantly greater. It should be noted that the adsorption capacity and accompanying gas-particle partitioning mechanisms for $\mathrm{Hg}$ species can change with the various conditions including particle composition and temperature; therefore complete understanding of this phenomenon will require 20 further investigation.

Acknowledgements. The authors acknowledge the New York State Energy Research and Development Authority (NYSERDA) for partially supporting this research (Gregory Lampman project officer). It has not been subject to the NYSERDA's peer and policy review and, therefore, does not necessarily reflect the views of NYSERDA and no official endorsement should be inferred. This research was also supported in part by Kangwon National University and by Basic Science Research Program through the National Research Foundation of Korea (NRF) funded by the Ministry of Education, Science and Technology (2012R1A1A2042150).

\section{ACPD}

13, 8585-8614, 2013

\section{Particulate bound mercury and associated artifacts \\ S. Wang et al.}

Title Page

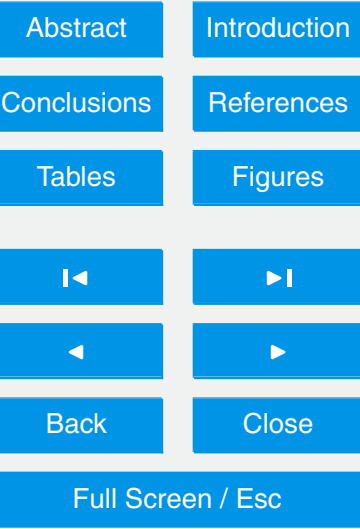

Printer-friendly Version

Interactive Discussion 


\section{References}

Andersson, M. E., Gardfeldt, K., Wangberg, I., Sprovieri, F., Pirrone, N., and Lindqvist, O.: Seasonal and daily variation of mercury evasion at coastal and off shore sites from the Mediterranean Sea, Marine Chem., 104, 214-226, 2007.

5 Choi, H.-D., Holsen, T. M., and Hopke, P. K.: Atmospheric Mercury (Hg) in the Adirondacks: Concentrations and Sources, Environ. Sci. Technol., 42, 5644-5653, 2008.

Ci, Z. J., Zhang, X. S., Wang, Z. W., Niu, Z. C., Diao, X. Y., and Wang, S. W.: Distribution and air-sea exchange of mercury $(\mathrm{Hg})$ in the Yellow Sea, Atmos. Chem. Phys., 11, 2881-2892, doi:10.5194/acp-11-2881-2011, 2011.

Cobbett, F. D., Steffen, A., Lawson, G., Bill, J., and Heyst, V.: Measurements of GEM fluxes and atmospheric mercury concentrations (GEM, RGM and $\mathrm{PHg}$ ) from an agricultural field amended with biosolids in Southern Ont., Canada (October 2004-November 2004), Atmos. Environ., 41, 2270-2282, 2007.

Copley, M.: Understanding cascade impactor and its importance for inhaler testing, avilable at: http://www.copleyscientific.com/documents/ww_fr/Understanding\%20Cascade\% 20Impaction\%20White\%20Paper.pdf, 2007.

Driscoll, C. T., Han, Y. J., Chen, C. Y., Evers, D. C., Lambert, K. F., Holsen, T. M., Kamman, N. C., and Munson, R. K.: Mercury contamination in forest and freshwater ecosystems in the Northern United States, BioScience, 57, 17-28, 2007.

Dvonch, J. T., Vette, A. F., Keeler, G. J., Evans, G., and Stevens, R.: An intensive multi-site pilot study investigating atmospheric mercury in Broward County, Florida, Water Air Soil Pollut., 80, 169-178, 1995.

Feng, X., Hong, Y., Hong, B., and Ni, J.: Mobility of some potentially toxic trace elements in the coal of Guizhou, Environ. Geol., 39, 372-377, 2000.

Feng, X., Lu, J. Y., Conrad, D. G., Hao, Y., Banic, C. M., and Schroeder, W. H.: Analysis of inorganic mercury species associated with airborne particulate matter/aerosols: method development, Anal. Bioanal. Chem., 380, 683-689, 2004.

Fleming, E. J., Mack, E. E., Green, P. G., and Nelson, D. C.: Mercury methylation from unexpected sources: molybdate-inhibited freshwater sediments and an iron-reducing bacterium, $30 \quad$ Appl. Environ. Microbiol., 72, 457-464, 2006.

Graney, J. R., Dvonch, J. T., and Keeler, G. J.: Use of multi-element tracers to source apportion mercury in south Florida aerosols, Atmos. Environ., 38, 1715-1726, 2004.
ACPD

13, 8585-8614, 2013

\section{Particulate bound \\ mercury and \\ associated artifacts \\ S. Wang et al.}

Title Page

Abstract

Introduction

Conclusions

References

Tables

Figures

14

$>1$

4

Back

Close

Full Screen / Esc

Printer-friendly Version

Interactive Discussion 
Gustin, M. S.: Are mercury emissions from geologic sources significant? A status report, Sci. Total Environ., 304, 153-167, 2003.

Hays, M. D., Geron, C. D., Linna, K. J., Smith, N. D., and Schauer, J. J.: Speciation of gasphase and fine particle emissions from burning of foliar fuels, Environ. Sci. Technol., 36, 2281-2295, 2002.

Hinds, W. C.: Aerosol Technology; Properties, Behavior, and Measurement of Airborne Particles. John Wiley \& Sons, New York, NY, 1999.

Hosseini, S., Li, Q., Cocker, D., Weise, D., Miller, A., Shrivastava, M., Miller, J. W., Mahalingam, S., Princevac, M., and Jung, H.: Particle size distributions from laboratory-scale biomass fires using fast response instruments, Atmos. Chem. Phys., 10, 8065-8076, doi:10.5194/acp-108065-2010, 2010.

Huang, J., Choi, H.-D., Landis, M. S., and Holsen, T. M.: An application of passive samplers to understand atmospheric mercury concentration and dry deposition spatial distributions, J. Environ. Monit., 14, 2976-2982, 2012.

15 Keeler, G., Hoyer, M., and Lamborg, C.: Measurements of atmospheric mercury in the Great Lakes Basin, 231-241, edited by: Watras, C. J. and Huckabee, J. W., Mercury Pollution Integration and Synthesis, 1994.

Keeler, G., Glinsorn, G., and Pirrone, N.: Particulate mercury in the atmosphere Its significance, transport, transformation and sources, Water Air Soil Pollut., 80, 159-168, 1995.

Kim, P. R., Han, Y. J., Holsen, T. M., and Yi, S. M.: Atmospheric particulate mercury: Concentrations and size distributions, Atmos. Environ., 61, 94-102, 2012.

Kim, S. H., Han, Y. J., Holsen, T. M., and Yi, S. M.: Characteristics of atmospheric speciated mercury concentrations (TGM, $\mathrm{Hg}(\mathrm{II})$ and $\mathrm{Hg}(\mathrm{p})$ ) in Seoul, Korea, Atmos. Environ., 43, 32673274, 2009.

Kocman, D. and Horvat, M.: A laboratory based experimental study of mercury emission from contaminated soils in the River Idrijca catchment, Atmos. Chem. Phys., 10, 1417-1426, doi:10.5194/acp-10-1417-2010, 2010.

Lai, S.-O., Hunag, J., Hopke, P. K., and Holsen, T. M.: An evaluation of direct measurement techniques for mercury dry deposition. Sci. Total Environ., 409, 1320-1327, 2011.

30 Lamborg, C. H., Fitzgerald, W. F., Vandal, G. M., and Rolfus, K. R.: Atmospheric mercury in northern Wisconsin: sources and species, Water Air Soil Pollut., 80, 189-198, 1995. 
Landis, M. S., Stevens, R. K., Schaedlich, F., and Prestbo, E. M.: Development and Characterization of an Annular Denuder Methodology for the Measurement of Divalent Inorganic Reactive Gaseous Mercury in Ambient Air, Environ. Sci. Technol., 36, 3000-3009, 2002.

Lee, S.-R., Holsen, T. M., and Dhaniyala, S.: Design and Development of Novel Large Particle Inlet for PM Larger Than $10 \mu \mathrm{m}$ (PM> 10), Aerosol Sci. Tech., 42, 140-151, 2008.

$\mathrm{Li}$, Z., Sun, X., Luo, J., and Hwang, J. Y.: Unburned carbon from fly ash for mercury adsorption: II. Adsorption isotherms and mechanisms, J. Minerals \& Materials Characterization \& Engineering, 1, 79-96, 2002.

Lin, H. Y., Yuan, C. S., Chen, W. C., and Hung, C. H.: Determination of the adsorptive capacity and adsorption isotherm of vapor-phase mercury chloride on powdered activated carbon using thermogravimetric analysis, J. Air Waste Manag. Assoc., 56, 1550-1557, 2006.

Lindberg, S. E. and Stratton, W. J.: Atmospheric Mercury Speciation: Concentrations and Behavior of Reactive Gaseous Mercury in Ambient Air, Environ. Sci. Technol., 32, 49-57, 1998.

Lyman, S. N., Jaffe, D. A., and Gustin, M. S.: Release of mercury halides from $\mathrm{KCl}$ denuders in the presence of ozone, Atmos. Chem. Phys., 10, 8197-8204, doi:10.5194/acp-10-81972010, 2010.

Lynam, M. M. and Keeler, G. J.: Artifacts associated with the measurement of particulate mercury in an urban environment: The influence of elevated ozone concentrations, Atmos. Environ., 39, 3081-3088, 2005.

20 Malcolm, E. G. and Keeler, G. J.: Evidence for a sampling artifact for particulate-phase mercury in the marine atmosphere, Atmos. Environ., 41, 3352-3359, 2007.

Mergler, D., Anderson, H. A., Chan, L. H., Mahaffey, K. R., Murray, M., Sakamoto, M., and Stern, A. H.: Panel on Health Risks and Toxicological Effects of Methylmercury: Methylmercury Exposure and Health Effects in Humans: A Worldwide Concern, Ambio, 36, 3-11, 2007.

NADP: Draft Standard Operating Procedures for Analysis of Gaseous and Fine ParticulateBound Mercury, Champaign, IL, 2008.

Pirrone, N., Cinnirella, S., Feng, X., Finkelman, R. B., Friedli, H. R., Leaner, J., Mason, R., Mukherjee, A. B., Stracher, G. B., Streets, D. G., and Telmer, K.: Global mercury emissions to the atmosphere from anthropogenic and natural sources, Atmos. Chem. Phys., 10, 59515964, doi:10.5194/acp-10-5951-2010, 2010.

Poissant, L., Pilote, M., Beauvais, C., Constant, P., and Zhang, H. H.: A year of continuous measurements of three atmospheric mercury species (GEM, RGM and Hgp) in southern Québec, Canada, Atmos. Environ., 39, 1275-1287, 2005.
ACPD

13, 8585-8614, 2013

\section{Particulate bound \\ mercury and \\ associated artifacts \\ S. Wang et al.}

Title Page 
Rutter, A. P. and Schauer, J. J.: The effect of temperature on the gas-particle partitioning of reactive mercury in atmospheric aerosols, Atmos. Environ., 41, 8647-8657, 2007a.

Rutter, A. P. and Schauer, J. J.: The impact of aerosol composition on the particle to gas partitioning of reactive mercury, Environ. Sci. Technol., 41, 3934-3939, 2007b.

5 Schroeder, W. H. and Munthe, J.: Atmospheric mercury - an overview, Atmos. Environ., 32, 809-822, 1998.

Sheu, G.-R. and Mason, R. P.: An examination of methods for the measurements of reactive gaseous mercury in the atmosphere, Environ. Sci. Technol., 35, 1209-1216, 2001.

Talbot, R., Mao, H., Feddersen, D., Smith, M., Kim, S. Y., Sive, B., Haase, K., Ambrose, J., Zhou,

10 Y., and Russo, R.: Comparison of particulate mercury measured with manual and automated methods, Atmosphere, 2, 1-20, 2011.

US EPA: Mercury study report to Congress, Office of Air Quality Planning and Standards and Office of Research and Development, 1997.

US EPA: Mercury Update: Impact in Fish Advisories. U.S. Environmental Protection Agency, Office of Water. 4305. EPA-823-F-01-011, 2001.

US EPA: Method 1631, Revision E: Mercury in Water by Oxidation, Purge and Trap, and Cold Vapor Atomic Fluorescence Spectrometry, US Environmental Protection Agency, Office of Water. EPA-821/R-02e019, 2002.

Valente, R. J., Shea, C., Lynn Humes, K., and Tanner, R. L.: Atmospheric mercury in the Great

20 Smoky Mountains compared to regional and global levels, Atmos. Environ., 41, 1861-1873, 2007.

Weiss-Penzias, P., Gustin, M. S., and Lyman, S. N.: Observations of speciated atmospheric mercury at three sites in Nevada: Evidence for a free tropospheric source of reactive gaseous mercury, J. Geophys. Res., 114, D14302, doi:10.1029/2008JD011607, 2009.

Xin, M. and Gustin, M. S.: Gaseous elemental mercury exchange with low mercury containing soils: Investigation of controlling factors, Applied Geochemistry, 22, 1451-1466, 2007.

Xin, M., Gustin, M., and Johnson, D.: Laboratory investigation of the potential for re-emission of atmospherically derived $\mathrm{Hg}$ from soils, Environ. Sci. Technol., 41, 4946-4951, 2007.

Xiu, G. L., Jin, Q., Zhang, D., Shi, S., Huang, X., Zhang, W., Bao, L., Gao, P., and Chen, B.: 30 Characterization of size-fractionated particulate mercury in Shanghai ambient air, Atmos. Environ., 39, 419-427, 2005.

\section{Particulate bound \\ mercury and \\ associated artifacts \\ S. Wang et al.}

Title Page 
Xiu, G., Cai, J., Zhang, W., Zhang, D., Bueler, A., Lee, S., Shen, Y., Xu, L., Huang, X., and Zhang, P.: Speciated mercury in size-fractionated particles in Shanghai ambient air, Atmos. Environ., 43, 3145-3154, 2009.

Zhang, L., Wright, L. P., and Blanchard, P.: A review of current knowledge concerning dry 5 deposition of atmospheric mercury, Atmos. Environ., 43, 5853-5864, 2009.

\section{ACPD}

13, 8585-8614, 2013

Particulate bound mercury and associated artifacts

S. Wang et al.

\section{Title Page}

Abstract

Conclusions

Tables

14

4

Back

Full Screen / Esc

Printer-friendly Version

Interactive Discussion 


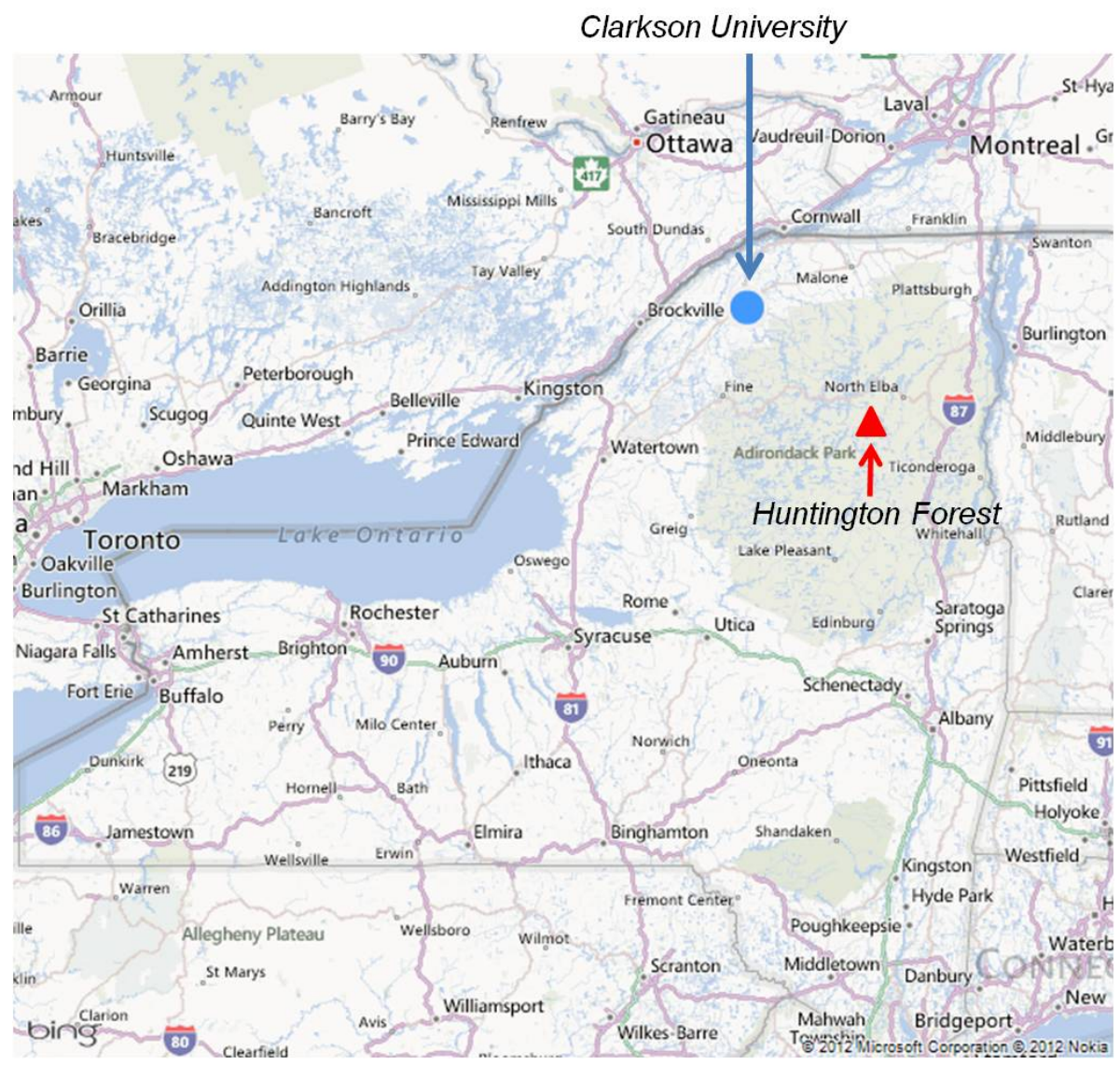

Fig. 1. Two sampling sites located at Clarkson University (CU) in Potsdam and Huntington Wildlife Forest in Adirondack Park (HF) in New York State.
ACPD

$13,8585-8614,2013$

\section{Particulate bound mercury and associated artifacts}

S. Wang et al.

\section{Title Page}

Abstract

Introduction

Conclusions

References

Tables

Figures

14

4

Back

Close

\section{Full Screen / Esc}

Printer-friendly Version

Interactive Discussion 


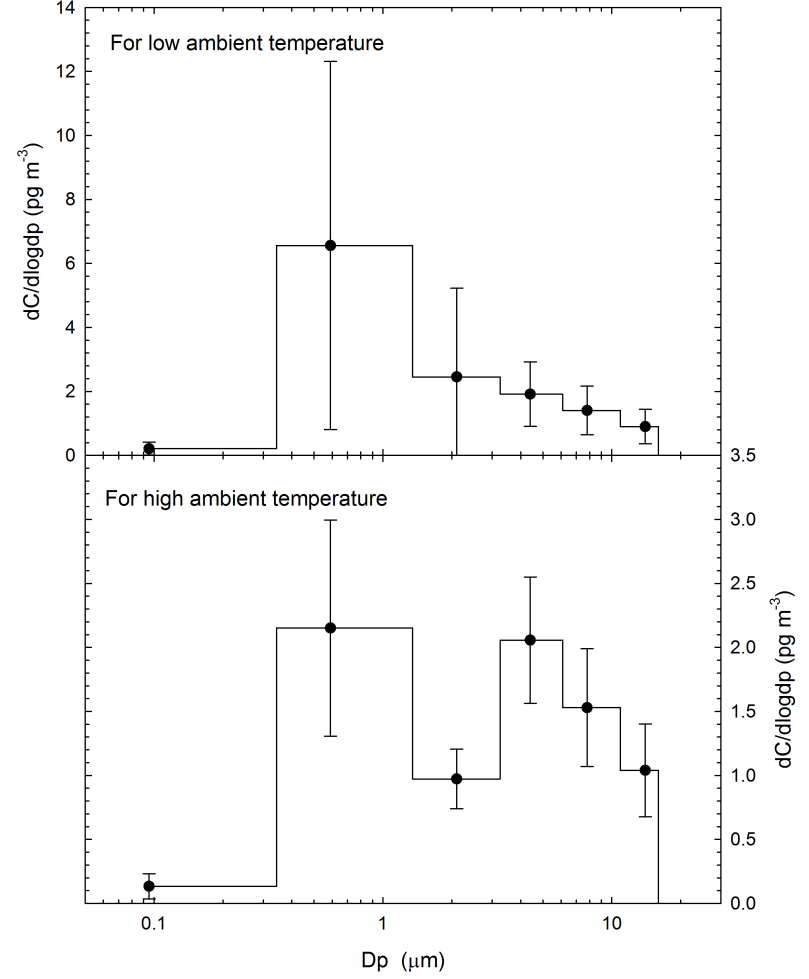

Fig. 2. Size distribution of PBM by MOUDI. PBM shifted toward to coarser mode when the atmospheric temperature was low. The error bar indicates one standard deviation.

\section{ACPD}

13, 8585-8614, 2013

Particulate bound mercury and associated artifacts

S. Wang et al.

Title Page

Conclusions

References

Tables

Figures

14

Back

\section{Full Screen / Esc}

Printer-friendly Version

Interactive Discussion 


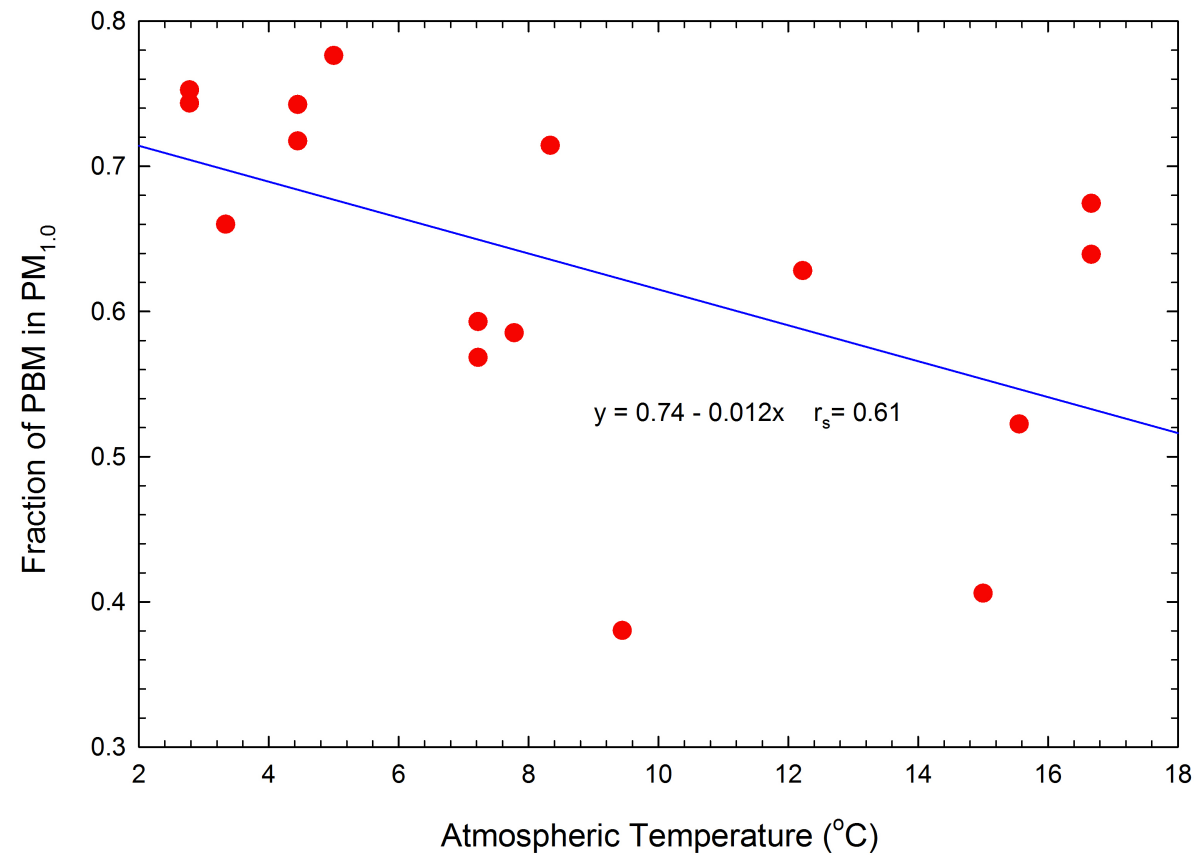

\section{ACPD}

13, 8585-8614, 2013

Particulate bound mercury and associated artifacts

S. Wang et al.

\section{Title Page}

\section{Full Screen / Esc}

Printer-friendly Version

Interactive Discussion 


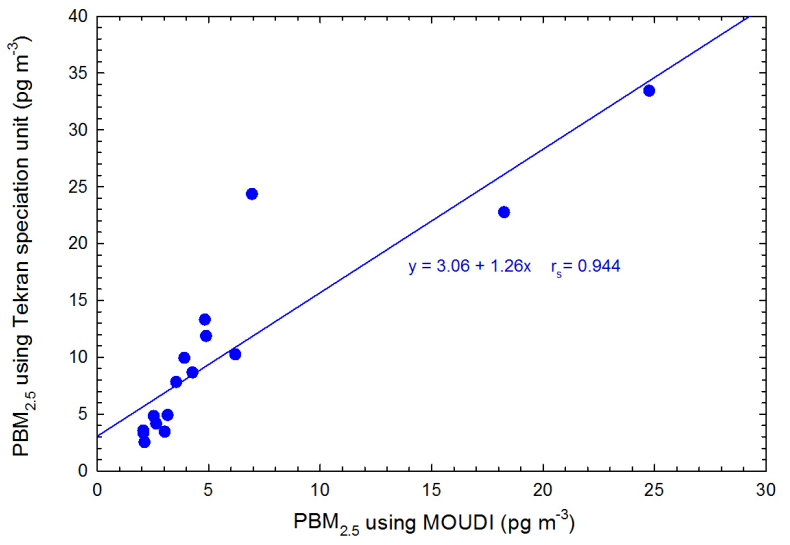

ACPD

13, 8585-8614, 2013

\section{Particulate bound} mercury and associated artifacts

S. Wang et al.

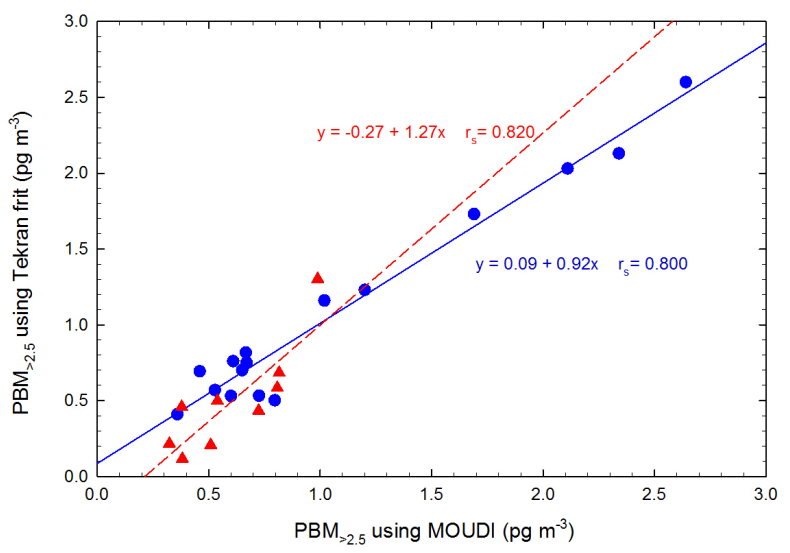

Title Page

Abstract

Conclusions

Tables

14

4

Back

Full Screen / Esc

Printer-friendly Version

Interactive Discussion

Fig. 4. Comparison between MOUDI and TekSpec for $\mathrm{PBM}_{2.5}$ (upper panel) and $\mathrm{PBM}_{>2.5}$ (lower panel). The blue circle and red triangle in lower panel indicate MOUDI results operated for 2 days at $\mathrm{CU}$ and for 7 days at HF, respectively. 


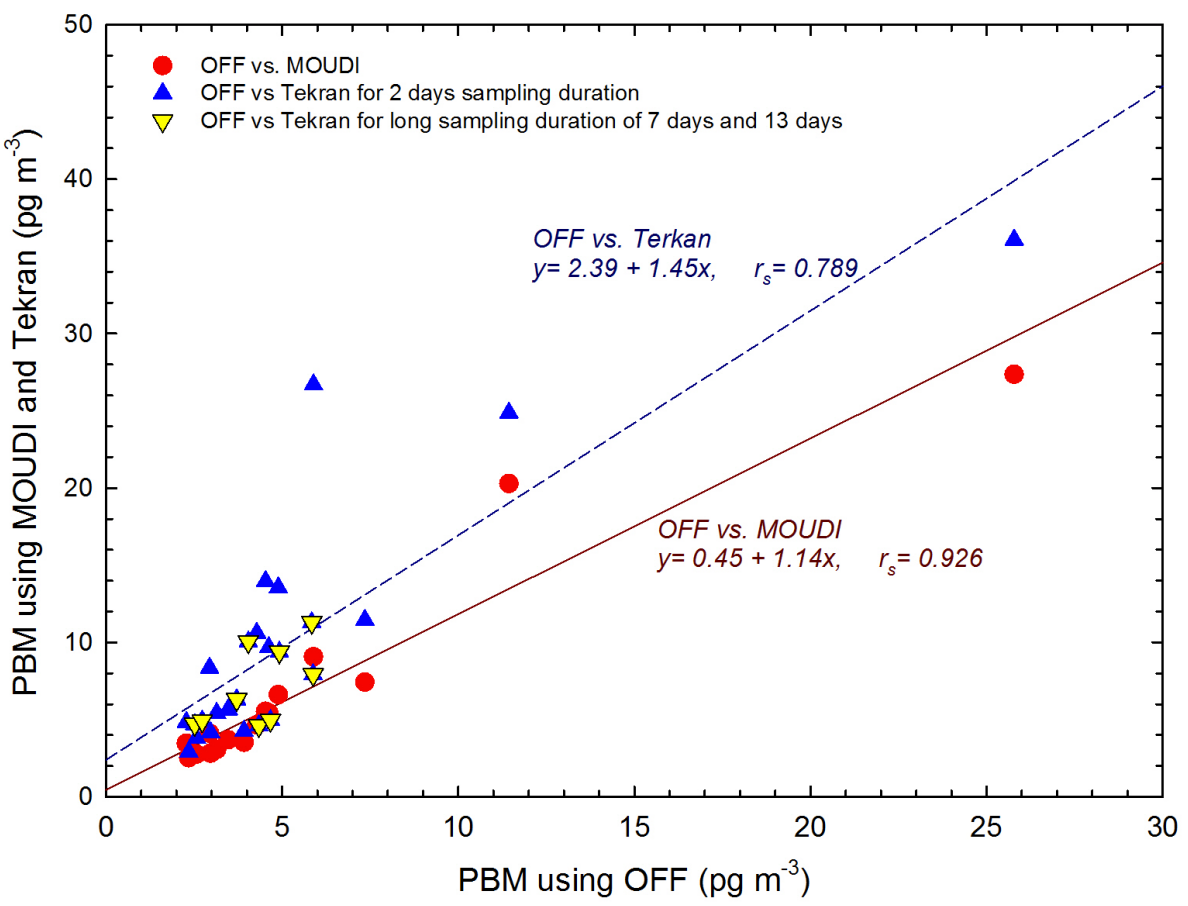

Fig. 5. Comparison of total PBM concentrations between OFF and MOUDI (red circle) and between OFF and TekSpec (blue triangle and yellow inverted triangle).

\section{ACPD}

13, 8585-8614, 2013

\section{Particulate bound mercury and associated artifacts}

S. Wang et al.

\section{Title Page}

Abstract

Conclusions

Tables

14

Back

Full Screen / Esc

Printer-friendly Version 


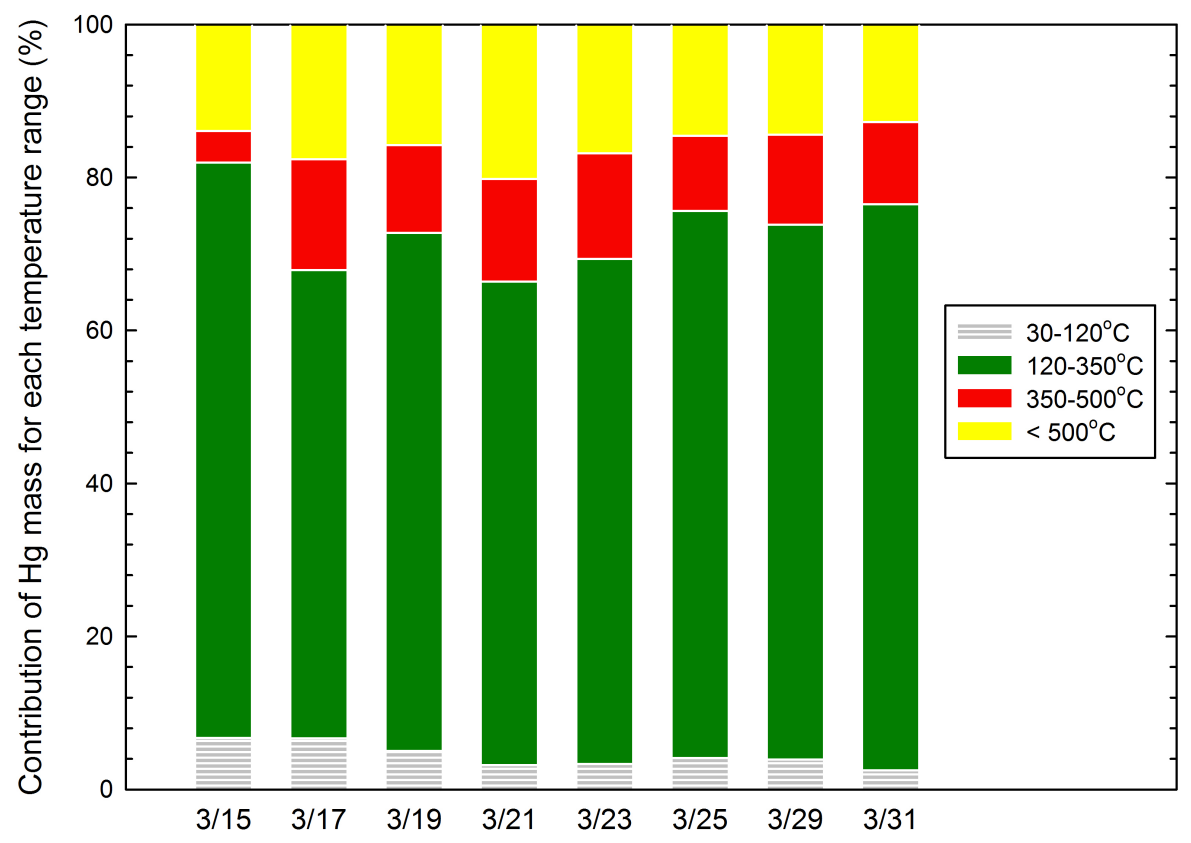

\section{ACPD}

13, 8585-8614, 2013

\section{Particulate bound} mercury and associated artifacts

S. Wang et al.

\section{Title Page}

Abstract Introduction

Conclusions

References

Tables

14

Back

Full Screen / Esc

Printer-friendly Version

Interactive Discussion 


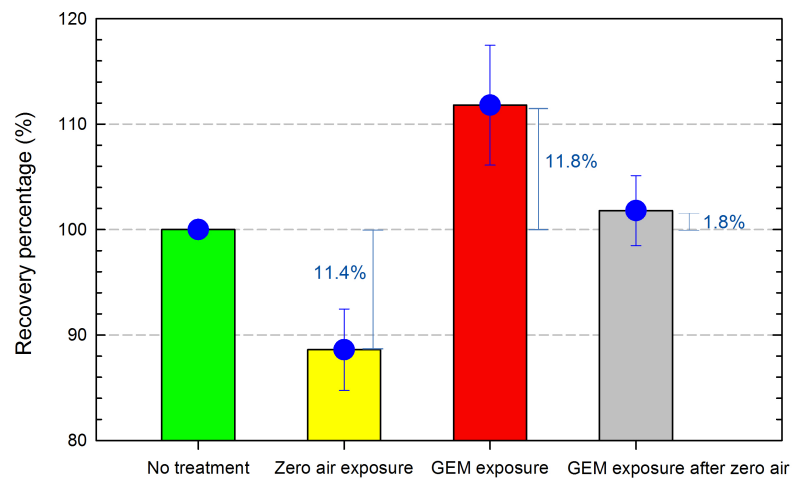

\section{ACPD}

13, 8585-8614, 2013

Particulate bound mercury and associated artifacts

S. Wang et al.

Title Page

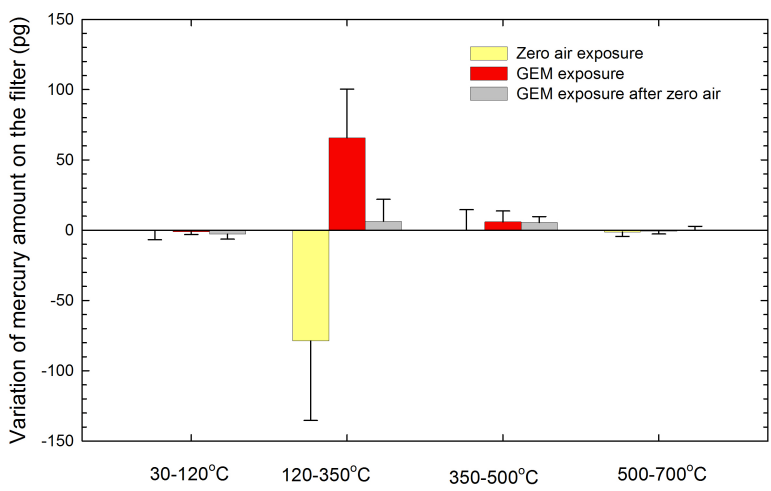

Abstract

Introduction

Conclusions

References

Tables

Figures

14

Back

$\triangleright$

Full Screen / Esc

Fig. 7. Upper panel: percentage of the total $\mathrm{Hg}$ recovered after four different treatments: (1) immediate analysis, (2) exposure to GEM, (3) exposure to zero air and (4) exposure to zero air followed by exposure to GEM. Lower panel: variation of $\mathrm{Hg}$ amount at different desorption temperatures after four treatments.

Interactive Discussion 


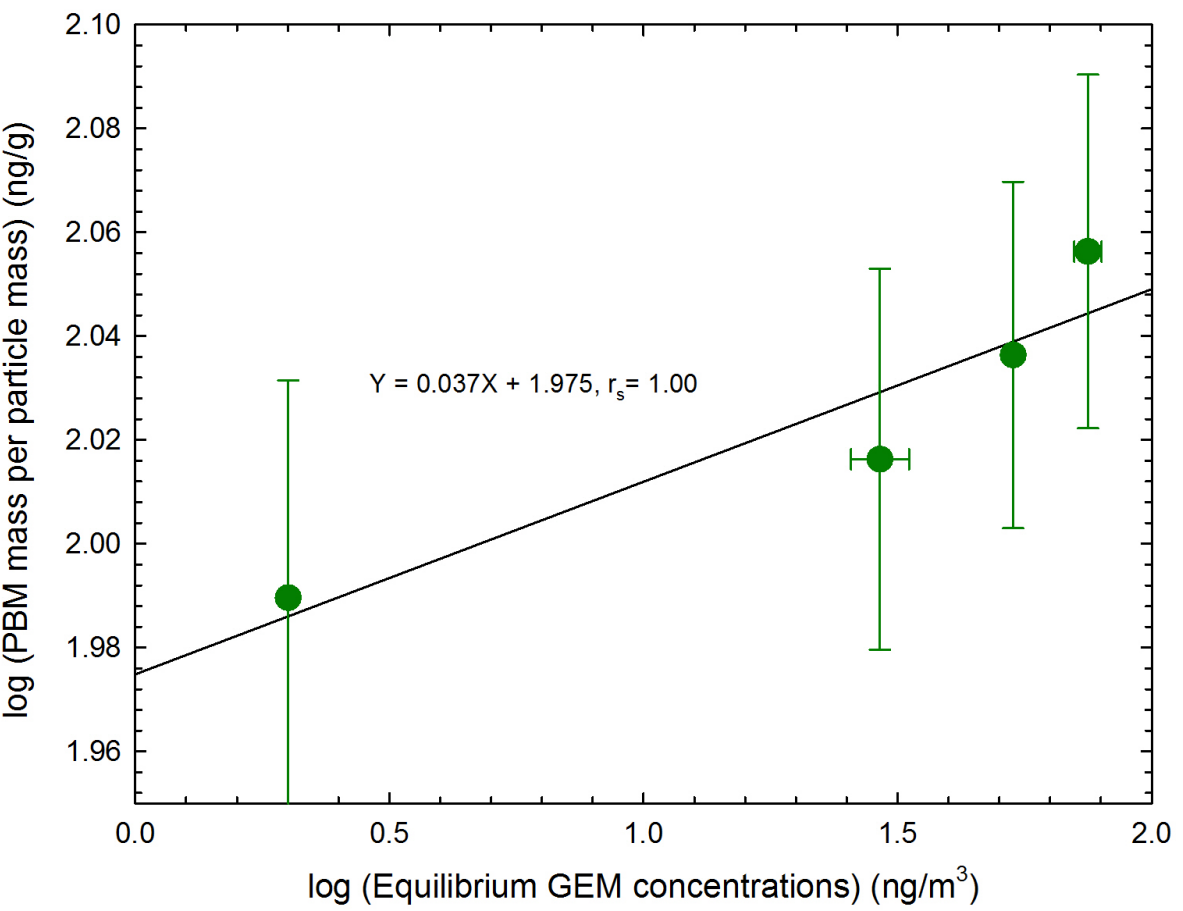

Fig. 8. Percentage increase in the PBM concentration after exposure to different GEM concentrations. The error bar indicates one standard deviation.

\section{ACPD}

13, 8585-8614, 2013

\section{Particulate bound} mercury and associated artifacts

S. Wang et al.

\section{Title Page}

Abstract

Introduction

Conclusions

References

Tables

Figures

14

Back

Close

\section{Full Screen / Esc}

Printer-friendly Version

Interactive Discussion 